\title{
Optical Characteristic Investigation on Copper Sulphide thin film for photovoltaic Applications
}

\author{
W. Christopher Immanuel ${ }^{1 *}$, S. Paul Mary Deborrah ${ }^{2}$, S.S.R. Inbanathan ${ }^{2}$ \\ ${ }^{1}$ Department of Physics, EGS Pillay Engineering College (Autonomous), Nagapattinam, Tamil Nadu, India \\ ${ }^{2}$ Department of Physics, American College, Madurai, Tamil Nadu, India
}

Available online at: www.isroset.org

Received: 02/Feb/2019, Accepted: 12/Feb/2019, Online: 28/Feb/2019

\begin{abstract}
Copper sulfide has been considered as the most superior optical and semiconductor material. The current fossil-fuel based economy has proven to be no longer sustainable, due to economical, political, and environmental concerns. The global demand of energy has additional than doubled during the last 40 years and the predictions show an expected increase of 50\% with respect to the current situation. This further raise in global consumption can be mostly attributed to developing countries, with countries like China and India and the Middle East region playing a major role among them. The constantly growing energy demand cannot be satisfied by currently-used non renewable energy sources, mainly fossil fuels. Among all types of renewable resources, solar energy has the greatest development potential, since it is the biggest energy source available on Earth. In particular photovoltaic (PV), which is the direct change of solar irradiation into electricity, offers a great number of advantages: not only it is a technology that produces clean energy from an "inexhaustible and mostly import-independent resource". Latest research findings indicate that possessions of thin film solar cells powerfully depend on the various deposition techniques chemical bath deposition (CBD) being unique of them. In this research, CBD method was used to deposit thin films of Copper (II) sulphide $\left(\mathrm{Cu}_{2} \mathrm{~S}\right)$ on glass substrates. Solutions of copper (II) sulphate, thiourea and tartaric acid were used to deposit $\mathrm{Cu}_{2} \mathrm{~S}$ thin films at constant temperature $40 \pm 2^{0} \mathrm{C}$. The optical properties of films were investigated. Optical properties like reflectance and transmittance and band gap were determined. Transmittance of $\mathrm{Cu}_{2} \mathrm{~S}$ thin films varied between $10 \%$ and $40 \%$ with wavelength of the light energy. This research explain optical characterization on $\mathrm{Cu}_{2} \mathrm{~S}$ for solar cell application. The Results of optical properties like transmittance, reflectance and band gap also reported.
\end{abstract}

Keywords- Semiconductors; $\mathrm{Cu}_{2} \mathrm{~S}$; Deposition Technique, Analysis

\section{INTRODUCTION}

Solar cells are the least devices that can be used as irradiance sensors or as samples for learning new solar materials. According to (1) energy from the sun is relatively clean and reliable than gas, coal, and oil. Solar energy is significantly abundant and pollution free (2). Thin film technology is utilized to fabricate solar cells that produce power for domestic and commercial uses. Solar energy system is reliable, easy to maintain and install. Desirable qualities of $\mathrm{Cu}_{2} \mathrm{~S}$ thin films for solar cell fabrication can be found by chemical bath deposition method. There is need to study and look for the best materials for fabrication of solar cells that convert efficiently solar energy to electrical power. This study was aimed at investigating the optical properties of $\mathrm{Cu}_{2} \mathrm{~S}$ thin films using chemical bath deposition (CBD) method.

\section{DEVELOPMENT OF SOLAR CELLS}

Energy demand has grown tremendously and this calls for research into harvesting eco-friendly and renewable sources.
The entire amount of solar energy received by earth each second is about $1.74 \times 10^{17} \mathrm{~W}$. If captured effectively, even a small portion of this energy can encounter rapidly growing energy demand of the world. Semiconductor materials with superior charge transporter mobility and relatively low cost semiconductors are needed. Energy delivered by the sun in one hour onto the earth can, if appropriately trapped, be utilized in one year.

\section{COPPER (I) SULPHIDE THIN FILMS AND SOLAR CELLS FABRICATED}

$\mathrm{Cu}_{2} \mathrm{~S}$ thin film is an II-VI compound and is known to be in numerous crystallographic and stoichiometric forms whose main advantage is for making low cost solar cells. In addition, it is easy to deposit and form respectable quality films from a variability of growth methods (3). Normally resistivity of $\mathrm{Cu}_{2} \mathrm{~S}$ decreases for the film covered at higher thickness, which is due to increase in grain size of the film at higher thickness (4). Refraction index of $\mathrm{Cu}_{2} \mathrm{~S}$ is proportional to the film thickness. Copper sulphide thin 
films consume been greatly and extensively studied. These films show small reflectance below $10 \%$ in the visible area.

\section{MATERIALS FOR THIN FILM DEPOSITION}

\section{Deposition of p-type $\mathrm{Cu}_{2} \mathrm{~S}$ thin films}

The copper (I) sulphide thin films require copper II sulphate $\left(\mathrm{CuSO}_{4}\right)$ as a basis of copper (II) ions and $0.1 \mathrm{M}$ thiourea $\left\{\mathrm{CS}\left(\mathrm{NH}_{2}\right)_{2}\right\}$ as a source of sulphide $\left(\mathrm{S}^{2-}\right)$ ions. The concentration of the Copper (II) sulphate was varied from $0.1 \mathrm{M}$ to $0.5 \mathrm{M}$ in the reaction bath. Tartaric acid $\left(\mathrm{H}_{6} \mathrm{C}_{4} \mathrm{O}_{6}\right)$ was used a complexing agent. De-ionized water was used to dissolve the solid compounds to form a homogenous reaction bath. The Hydrochloric acid was used to lower the $\mathrm{pH}$ of the precursor solution. A below table shows the Composition of reagents used to deposit copper (I) Sulphide $\left(\mathrm{Cu}_{2} \mathrm{~S}\right)$ thin films.

\begin{tabular}{|c|c|l|l|l|c|}
\hline $\begin{array}{l}\text { Copper (II) } \\
\mathrm{CuSO}_{4}\end{array}$ & sulphate & $\begin{array}{l}0.2 \mathrm{M} \\
\text { thiourea } \\
\text { volume } \\
(\mathrm{ml})\end{array}$ & $\begin{array}{l}0.2 \mathrm{M} \\
\text { tartaric } \\
\text { acid } \\
\text { volume } \\
(\mathrm{ml})\end{array}$ & $\mathrm{PH}$ & $\begin{array}{l}\text { Time } \\
(\mathrm{min})\end{array}$ \\
\hline $\begin{array}{c}\text { Concentration } \\
\pm 0.05\end{array}$ & $\begin{array}{c}\text { Volume } \\
(\mathrm{ml}) \\
\pm 0.5\end{array}$ & $\begin{array}{l}\mathrm{CS}\left(\mathrm{NH}_{2}\right)_{2} \\
\pm 0.5\end{array}$ & $\begin{array}{l}\mathrm{H}_{6} \mathrm{C}_{4} \mathrm{O}_{6} \\
\pm 0.01\end{array}$ & - & - \\
\hline $0.1 \mathrm{M}$ & 25 & 25 & 25 & 3 & 20 \\
\hline $0.2 \mathrm{M}$ & 25 & 25 & 25 & 3 & 20 \\
\hline $0.3 \mathrm{M}$ & 25 & 25 & 25 & 3 & 20 \\
\hline $0.4 \mathrm{M}$ & 25 & 25 & 25 & 3 & 20 \\
\hline $0.5 \mathrm{M}$ & 25 & 25 & 25 & 3 & 20 \\
\hline
\end{tabular}

Table.1. Composition of reagents used to deposit copper (I) Sulphide $\left(\mathrm{Cu}_{2} \mathrm{~S}\right)$ thin films

The bath constituents were heated to a temperature of $40 \pm 2{ }^{\circ} \mathrm{C}$. Using $\mathrm{pH}$ meter its $\mathrm{pH}$ was maintained at 3 by adding dilute $\mathrm{Hcl}$ drop wise while stirring for 20 minutes. Glass substrate was dipped vertically into the deposition bath for about ten minutes. The glass substrate was detached from the beaker and washed in de-ionized water to remove the loosely adhered powder precipitates in the solution during deposition and then dried in air at room temperature. Concentration of $\mathrm{CuSO}_{4}$ was varied from $0.1 \mathrm{M}$ to $0.6 \mathrm{M}$ at intervals of $0.1 \mathrm{M}$.

\section{OPTICAL PROPERTIES OF P-TYPE $\mathrm{CU}_{2} \mathrm{~S}$}

UV-VIS NIR 3700 Spectrophotometer was used to measure transmittance and reflectance. The energy gap of the thin film is obtained by plotting $(\alpha h v)^{2}$ versus photon energy (hv)(5).

\section{A. Transmittance}

Figure 1 shows the optical transmittance spectra of $\mathrm{Cu}_{2} \mathrm{~S}$ thin films of dissimilar concentrations measured as a purpose of wavelength in the range of $300 \mathrm{~nm}$ to $1200 \mathrm{~nm}$ of incident photons.

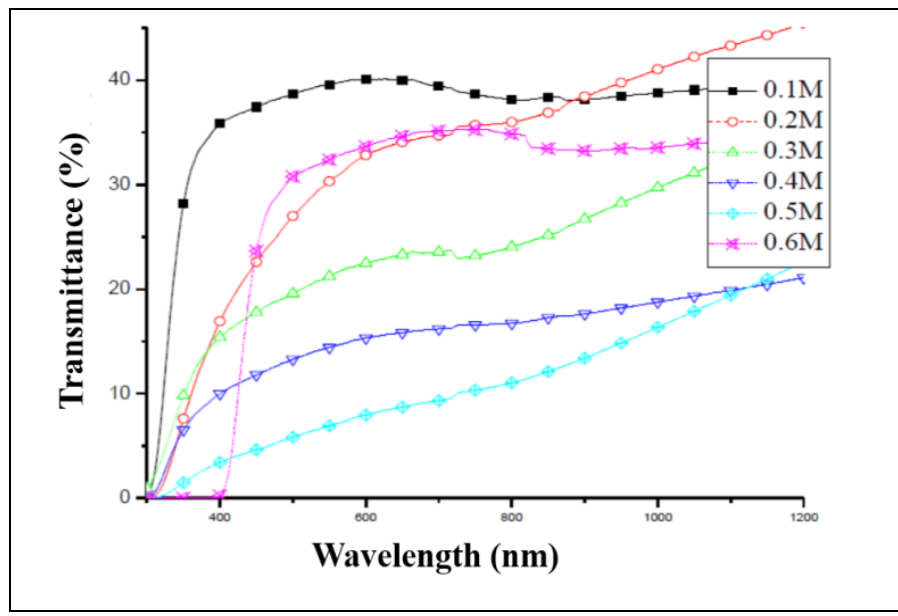

Fig. 1. Transmittance (T) as a function of wavelength $(\lambda)$ for $\mathrm{Cu}_{2} \mathrm{~S}$ thin films

The transmission curves show that transmittance is relatively low (below 40\%). The curves reveal that $\mathrm{Cu}_{2} \mathrm{~S}$ thin films are less transparent. Comparable results were obtained by (6) as having a transmittance of $42 \%$. In the shorter wavelength, transmission is caused by inter band transitions from valence band to the conduction band. The higher wavelength area the transmission is as a result of free carriers (7). This is explained by incomplete nucleation step with irregular growth amount of the thin film. Therefore the optimum molar concentration of $0.5 \mathrm{M}$ that gave the lowest transmittance was selected to deposit p-type $\mathrm{Cu}_{2} \mathrm{~S}$ thin films for solar cell application. The $\mathrm{Cu}_{2} \mathrm{~S}$ is a poor transmitter of photons incident on the film but a good absorber.

\section{B. Reflectance}

Figure 2 shows the reflectance spectra of $\mathrm{Cu}_{2} \mathrm{~S}$ for the wavelength between 300-1200nm.

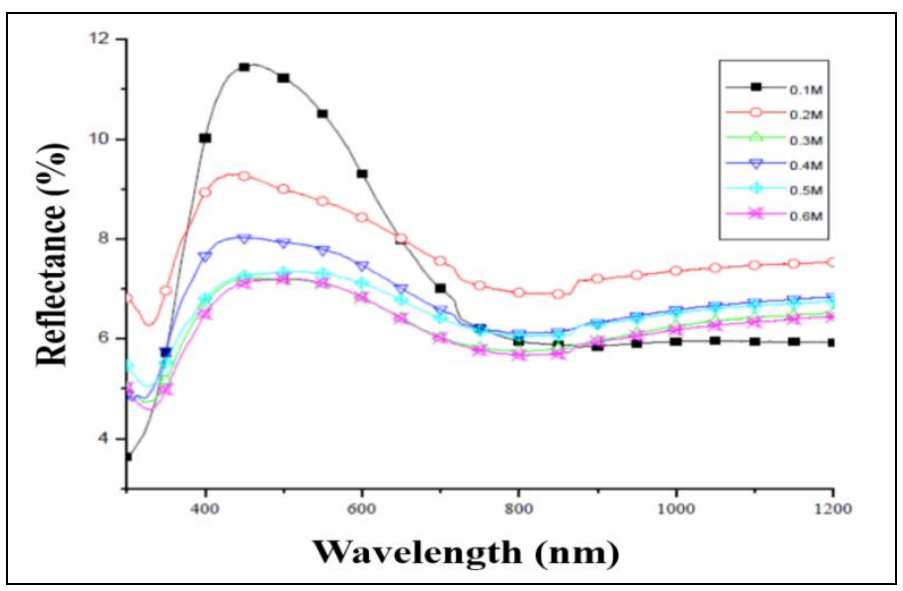

Fig. 2. Reflectance (R) as a function of wavelength $(\lambda)$ for $\mathrm{Cu}_{2} \mathrm{~S}$ thin films. 
It is observed that the thin film with least $(0.1 \mathrm{M})$ concentration of copper (II) ions reflects more light as shown (about 11\%) whereas the thin film with highest concentration $(0.6 \mathrm{M})$ has least reflectance of about $7 \%$. Reflectance spectra show that $\mathrm{Cu}_{2} \mathrm{~S}$ is poor reflector because the low percentage reflectance between 7 and $11 \%$. The film thickness of copper (II) ions growths with increase in the concentration of copper (II) ions in the substrate (8)(9). The resulting reflectance shows that the $\mathrm{Cu}_{2} \mathrm{~S}$ thin films deposited are poor reflectors of light therefore suitable for $\mathrm{p}$ type material for solar cell applications(10). There is sharp decrease of reflectance above $500 \mathrm{~nm}$ wavelength for all thin films. This observation can be explained as a result of high transmission of photons.

\section{Band gap}

Figure 3 shows variation of $(\alpha h v)^{2}$ against Energy (hv) between wavelength. The energy band gaps of $\mathrm{Cu}_{2} \mathrm{~S}$ were

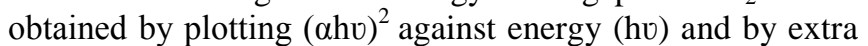
plotting the linear part of the curve.

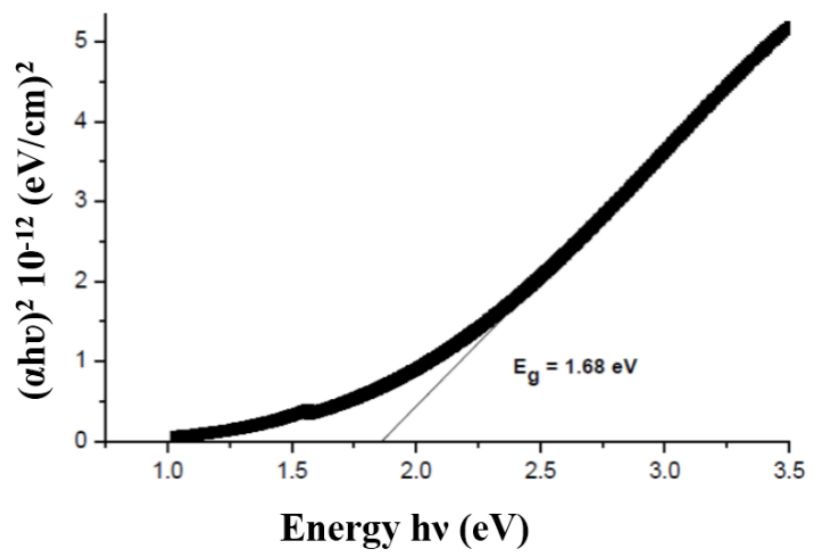

Fig. 3. Variation of $(\alpha h v)^{2}$ against Energy (hv) between wavelength.

The band gaps obtained were tabulated in Table 2. The results indicate that energy gap reductions with increase in film thickness. The decrease in the band gap is due to existence of internal electric field with defect in the film, increase in grain size due to re-crystallization of smaller particles (11).

\begin{tabular}{|c|c|c|c|}
\hline $\begin{array}{l}\text { Thin Film } \\
\text { No. }\end{array}$ & $\begin{array}{l}\text { Concentration of } \\
\mathrm{Cu}_{2}+\text { ions }\end{array}$ & $\begin{array}{l}\text { Energy Gap } \\
(\mathrm{eV})\end{array}$ & $\begin{array}{ll}\text { Film } & \text { Thickness } \\
(\mathrm{mm}) & \text { Error: } \quad \pm \\
0.05 & \end{array}$ \\
\hline 1 & $0.1 \mathrm{M}$ & $\begin{array}{c}2.24 \pm \\
0.00380\end{array}$ & 300 \\
\hline 2 & $0.2 \mathrm{M}$ & $\begin{array}{c}1.92 \pm \\
0.00389\end{array}$ & 305 \\
\hline 3 & $0.3 \mathrm{M}$ & $1.88 \pm$ & 307 \\
\hline
\end{tabular}

\begin{tabular}{|c|c|c|c|}
\hline & & 0.00295 & \\
\hline 4 & $0.4 \mathrm{M}$ & $1.84 \pm$ & 310 \\
& & 0.00608 & \\
\hline 5 & $0.5 \mathrm{M}$ & $1.68 \pm 0.0085$ & 326 \\
\hline 6 & $0.6 \mathrm{M}$ & $2.64 \pm$ & 350 \\
& & 0.00316 & \\
\hline
\end{tabular}

Table. 2. Energy Gaps obtained of different film thickness.

The Energy gap of the thin film number six $(0.6 \mathrm{M})$ is expressively higher due to rapid uncontrolled precipitation in the solution. This is explained by incomplete nucleation step with irregular growth rate of the thin film. The thin film number 5 was selected as the best choice because of its least energy gap.

\section{CONCLUSIONS}

$\mathrm{Cu}_{2} \mathrm{~S}$ thin films were effectively deposited on glass substrates by chemical bath deposition method. The optical properties of the thin films were investigated. The transmittance, reflectance and energy band gaps measurements of thin films that gave optimum properties were selected to fabricate a solar cell. $\mathrm{Cu}_{2} \mathrm{~S}$ was found to be a poor transmitter (7 to $38 \%$ ), poor reflector (6\% to $7 \%$ ) and good absorber (52.45 to $78.72 \%$ ). Band gaps varied between 1.68 to $2.64 \mathrm{eV}$. Band gaps decreased with escalation in the concentration of copper (II) ions. In view of the above reported characteristics of the solar cell, it was concluded that the material chosen can be suitably used to improve the output of the solar cells.

\section{REFERENCES}

[1]. G.R. Boyle, "Renewable energy: Power for a sustainable future", Oxford University Press, New York, pp. 181-226, 1996.

[2]. R.M. Nault, "Basic research needs for solar energy utilization", In the proceeding of a seminar on the basic energy sciences workshop on solar energy utilization, Argonne National Laboratory, pp. 3-10, 2005.

[3]. L.I. Maissel, R. Glang, "Hand book of thin film Technology", McGraw Hill, New York, 1970.

[4]. M. Ramya, S. Ganesan, "Annealing effects on resistivity properties of vacuum evaporated $\mathrm{Cu} 2 \mathrm{~S}$ thin films", International Journal of Pure and Applied Physics, Vol. 6, No.,3, pp. 243-249, 2010.

[5]. I. Ugwu, U. Onah, "Optical characteristics of chemical bath deposited CdS thin film characteristics within UV, Visible, and NIR radiation", The Pacific Journal of Science and Technology, Vol. 8, No.,1, pp. 155-161, 2007.

[6]. P. Parreira, G. Lavareda, J. Valente, F.T. Nunes, V. Amaral, C. Nunes, "Optoelectronic properties of transparent p-type semiconductor $\mathrm{Cu}_{\mathrm{x}} \mathrm{S}$ thin films". Physica Status Solidi, Vol. 207, pp. 1652-1654, 2010.

[7]. R.K. Das, "Preparation of $\mathrm{ZnO}$ Nanorods by Hydrothermal Process at Different Temperatures", International Journal of Scientific Research in Physics and Applied Sciences, vol.5, Issue 5, pp. 12-15, 2017. 
[8]. K.U. Isah, H. Narayan, A. Oberafo, "Optimization of process parameters of Chemical Bath Deposition of $\mathrm{Cd}_{1-\mathrm{x}} \mathrm{Zn}_{\mathrm{x}} \mathrm{S}$ thin film", Leonado Journal of Sciences, Vol.12, pp.111-120, 2008.

[9]. S.A.A. Oloomi, A. Saboonchi, A. Sedaghat, "Effects of thin film thickness on emittance, reflectance and transmittance of Nano scale multilayers". International Journal of Physical Science, Vol.5, Issue., 5, pp.465-469, 2010.

[10]. O.E. Osoro, "Characterization of $\mathrm{Cu}_{\mathrm{x}} \mathrm{O}_{\mathrm{y}}-\mathrm{ZnO}$ :Sn P-N Junction for Solar Cell applications"(Master's Thesis), Department of Physics, Kenyatta University, 2011.

[11]. P.C. Raji, C. Sanjeeviraja, C. Ramachandran, "Thermal and structural properties of Spray Pyrolysed CdS thin film", Indian Academy of Sciences, Vol. 28, pp. 233-238, 2005. 